\title{
O campo expandido do pornô: Robert Mapplethorpe, a delicadeza, o detalhe
}

\author{
Moisés Oliveira Alves \\ Universidade do Estado da Bahia
}

\begin{abstract}
Resumo
O artigo elabora uma possível genealogia do campo expandido do pornô a partir das fotografias de Robert Mapplethorpe e sua aposta em plasticidades (genitálias, gestos, botânica) que possibilitem aliar paradoxalmente o pornô e a delicadeza e o que chamamos da potência do detalhe, a partir de uma leitura que convoca pensadores/as de nosso tempo presente nos estudos de artes, teoria e filosofia.
\end{abstract}

\section{Palavras-chave}

Pornô; Robert Mapplethorpe; delicadeza; campo ampliado das artes.

The expanded field of pornography: Robert Mapplethorpe, the refinement, the detail

\section{Abstract}

The paper develops a kind of possible expanded porn's field genealogy, concentrating its focus on photographs of Robert Mapplethorpe and his bet on plasticity (genitals, gestures, botany) that combine paradoxically porn and delicate art, in particular way called poetic of minimum according to thinkers of our present times in the studies of art, literary theory and philosophy.

\section{Key-words}

Porn; Robert Mapplethorpe; delicate art; expanded field of art.

* Professor de Teoria Literária da Universidade do Estado da Bahia/UNEB, Campus XVI. E-mail: moa.oliveiraalves@gmail.com 


\section{Visgos, cheiros, sour \& líquidos do corpo}

O que se constrói afinal sob o nome de pornografia? Alguns interventores defendem um posicionamento que extingue a diferença entre o pornô e 0 erótico, levando em consideração o desejo de uma historiografia da arte ocidental de manter-se higienizada, fora de qualquer circuito em que a geografia da cintura (pelos, genitálias, excrementos, dilatações, afetos), permaneça apartada e perca consequentemente a tarja que a legitimaria como uma plasticidade artística.

Essa ausência de distinção está orientada na desconstrução do valor como aquele que ergue as fronteiras imaginárias entre dois lados aparentemente opostos. 0 erotismo, segundo essa tendência, ganha legitimidade através de sua grafia (eros, nome de uma divindade) em contraposição à pornografia: etimologicamente conhecida como escrita de prostitutas, lance que relegará todos os objetos sob essa perspectiva a um degrau abaixo, à lógica do vil e do profano. Segundo Lynn Hunt (1999:12), o termo foi dicionarizado em língua inglesa apenas em 1857, embora tenha surgido "primeiramente" na terra de Napoleão, reportando-se a duas significações diferentes: textos sobre prostitutas (1769) e um pouco depois por volta de 1830 e 1840 "no sentido de escritos e imagens obscenos" (idem; 14). Se os cidadãos eram recomendados a manter-se longe desses objetos por questões de ordem religiosa e política, é no século XIX nos EUA que encontramos a primeira lei e consequentemente a condenação baseada na obscenidade. É visível que os artistas canonizados cujos trabalhos adotaram essas peculiaridades em diversas histórias tradicionais das artes literárias e picturais, tendem a ser encontrados sob a reverência e 0 abrigo do erótico: categoria que abranda e institucionaliza tanto a aproximação de uma plateia quanto a análise do corpus.

"O caráter incapturável do fenômeno erótico não cabe em definições precisas e cristalinas. Os domínios de Eros são nebulosos e movediços" (Branco, 2004: 7). Com esse argumento, fico com a impressão que cabe 
ao erótico fixar-se numa zona de indecibilidade, resguardado com segurança, num meio-tom, lá onde encontramos as metáforas e os interditos e, sobretudo, a chance de apossar-se do objeto via decifração/interpretação. 0 pornográfico seria, então, toda obra que (se) desloca desse lugar, esvaziando uma prática corriqueira de leitura e dominação de um consumo de arte baseado no estatuto da representação. Neste sentido, definir o que quer que seja como pornô a partir dessa tradição crítica torna-se mais fácil: quaisquer objetos que abram mão dos procedimentos da codificação, estratégia clássica de legitimação do artístico. Em outras palavras, o pornô produz o vazio a partir de uma materialidade que se entrega. Este não é o ponto de tensão com o qual fundo uma aliança. Em vez dessa lógica opositiva e taxonômica, prefiro aproximar-me de acordo com seu poder de afetação e, sobretudo, de sua inespecificidade. No entanto, pretendo insistir nesse exercício de elastecer, discutindo junto com esses territórios imaginários.

0 ponto de tensão entre essas duas vertentes é posto em xeque quando 0 pornográfico transborda, isto é, quando rompe com a lógica operante de nada guardar, fazendo do todo exposto, tudo explícito, um tipo de manifesto em que a cintura e seus países, gêneros e linguagens baixas ganham cintilância. Entendemos como baixo, o que tradicionalmente ficou fora de um conjunto de textos filosóficos (de Platão a Hegel, de Descartes a Kant), como as expressões que não demandavam ou produziam, nem eram merecedoras das intervenções do pensamento, por fazerem parte de uma cartografia cujos fluxos, líquidos, movimentos instintivos possuíam uma lógica própria; desobedecendo aquilo que sustentava a prática de análise e leitura da história da filosofia eurocentrada como a consciência e domínio de si conjugada a uma forma universal do sujeito; cabia à linguagem das artes figurar-se como um espelhamento dessas perspectivas teóricas e do universo de dentro dessa subjetividade soberana.

Aproximar-se desses confins do corpo, roçar nessa constelação seria rasurar a soberania da cabeça em relação ao quadril e, sobretudo, a 
legitimação da experiência corpórea, odorífica, táctil, auditiva, onírica produzida por nós, entre nossos encontros, fazendo tremer o estatuto do transcendente e metafísico. É necessário lembrar que é aí que começa a investida dessas linguagens nuas/explícitas como uma barbárie, no sentido benjaminiano do termo, isto é, um projeto de releitura das heranças para que a partir delas possamos nos reinventar, à medida que esse gesto de acolher e transformar 0 acontecido lança o corpo a ir mais e mais adiante. Ela é assim toda afirmativa, ele diz. Reparem que as barbáries que esforçam-se por criar uma horizontalidade entre a cabeça, os músculos e o quadril são sempre perigosas, à medida que, vira e mexe, produzem seus terrorismos afetivos, políticos e epistemológicos ${ }^{1}$; além de fundarem maneiras de estar-junto, zonas de existência, uso, abandono e retomada da corporeidade como espaço criativo.

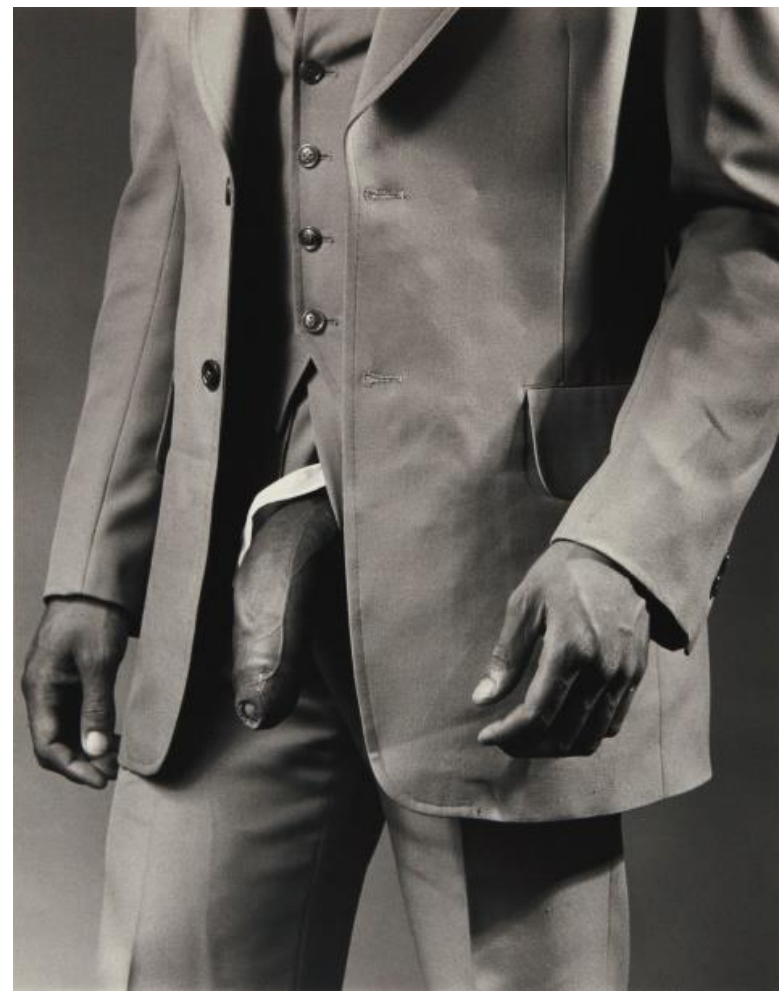

1 Acreditamos que as teorias queer/cuier, os estudos culturais, os diversos setores do debate feminista
(transfeminismo, feminismos de mulheres negras e indígenas), a abordagem transdisciplinar, o pornoterrorismo, as
expressões da cultura de massa (pagode, arrocha, merengue, funk) do pop, do popular, quando compreendidos
através da chave da radicalidade discursiva e do excesso por investirem num projeto de reversão no volume máximo,
sinalizam uma experiência da barbárie, mas dessa vez através das diferentes formas e sensibilidades latino-
americanas a partir de seus cenários pós-coloniais. Sobre a barbárie: (Benjamin, 1994: 115-116). Revista do Programa de Pós-graduação em Arte da UnB V.15, $\mathrm{n}^{0} 1$ /janeiro-junho de 2016 Brasilia
ISSN-1518-5494 ISSN (versão eletrônica):2447-2484 
Fig. 1. Man in Polyester Suit, 1980. Fonte: ROBERT MAPPLETHORPE FOUNDATION²

Como capturar a delicadeza do outro através do visgo, do cheiro, do suor, dos líquidos do corpo?

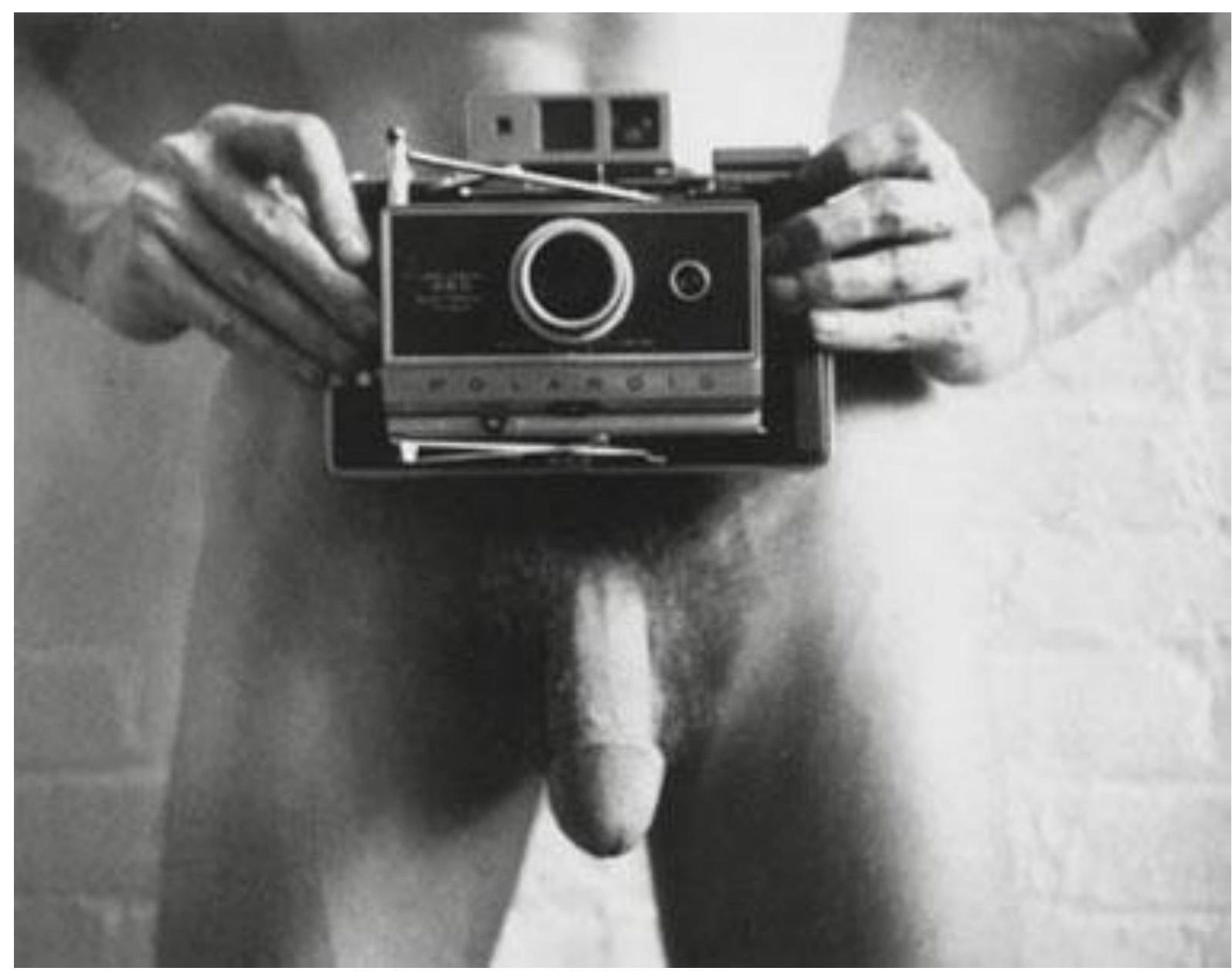

Fig. 2. Mapplethorpe. Selfportrait, 1973.

É chegada a hora de se escrever uma história das pornografias sob a tutela desses elementos inscritos por artistas fortes nas muitas linguagens áudio/visuais, destituindo o lugar tirano da exibição, narração e uso das genitálias como princípio motor do pornô. Voltar-se para outras intensidades do pornô - o gemido, o riso, o suor - é produzir uma história

\footnotetext{
2 Todas as fotografias desse artista presentes no texto estão disponíveis em: http://www.mapplethorpe.org/portfolios/ Acesso em maio de 2015. 
através de signos considerados tradicionalmente como acessórios e periféricos face a um centro imaginário em que o olhar se volta para formas culturalmente reprimidas, além de assumir a força discursiva de dispositivos corpóreos, porém imateriais. Essa narrativa desviante, essa aventura de pé no chão abriria mão de monumentalizar o genital quando se desinteressa por mantê-los no campo do biológico e/ou do puramente artístico, sensorial, cujos discursos ainda oscilantes à custa de não sabermos o que pode 0 corpo, alternarem entre a sacralização e a profanidade.

Erguer um pensamento histórico a partir do prazer talvez seja o porvir e o redimensionamento de valores e práticas de prazer. $\mathrm{O}$ que se propõe é a possibilidade de reler obras vistas como pornográficas, instaurando a partir delas questões estéticas irreconciliáveis para as histórias da arte, além da retomada oblíqua, torta do composto cênico (personagens, cenários, texto) a fim de elaborar paradigmas, modos de relação e heranças desviantes. Pensar os gemidos, o suor dos corpos, o inimaginável, aquilo que quase nunca se fotografa, o convencionalmente banido e produzido como inexistente ou inoperante. O suor possui também sua história (lutas, colônias, transas): ele é efeito de forças. Reinventar a nossa relação com a prática/performance e pensamento sexual aparece como um possível efeito coletivo dessa outra postura histórica úmida, meio pegajosa e sônica.

No pornô, o corpo em sua cena se deixa ver, deixa-se ser detalhado, desencapsulado. Como no mundo da criança, o mais assustador parece ser o mais óbvio: aquilo que tenho e não tenho ao mesmo tempo. Quem dera fôssemos advertidos, desde cedo, que o não ter não significa a presença de uma falta e sim a marca de uma diferença. Ainda: o objeto pornô participa, segundo Williams (1991:06), de um consumo no qual os excessos aparecem como uma oferenda, atravessando as práticas e políticas de subjetivação ou de assujeitamento, memórias coletivas, pedagogias restritivas, plasticidades selvagens, retomada - de mim e de você. 
Os male nudes de Robert Mapplethorpe (1946-1989), fotógrafo norteamericano, revigoram essa discussão. Com um legado extenso que atravessa experiências com escultura e paisagens, Mapplethorpe chamará atenção com imagens em preto e branco produzidas a partir de suas práticas de amizade, composta por celebridades da indústria da música e do cinema e principalmente anônimos em situação de nudez. Lisa Lyon, Patti Smith, William Burroughs, Tom Capote, Andy Warhol são alguns nomes que se tornaram personagens na ótica do artista, além dele mesmo conforme vemos em suas Self-Portraits. Uma delas de 1975 chamou a atenção do pensador francês Roland Barthes, presente em seu estudo sobre a fotografia cuja imagem o levou a pensar num tipo de erotismo alegre: o corpo em oferecimento deixa-se adivinhar, constituindo desse modo um ato sublime, generoso. (Barthes, 1984:89).

Ensaios que aderem à poética do cotidiano transformam-se em seu programa estético num espaço onde encontramos encenações do corpo, em flagrante, salvaguardados tanto da dor quanto do prazer. Posar para sua câmera mostra a possibilidade de dramatizarmos o que produzimos furtivamente com as mãos, o entrelaçar das pernas, a chegada de um olhar no outro.

Como espaço ligado a um desejo democrático ${ }^{3}$, as fotografias de Mapplethorpe negam a ação paisagística, relação arcádica atrelada à história de recepção de imagens através da contemplação estética, maneira mais tradicional de encontrar-se com a arte. Tudo nele se dá de modo maleável, macio e simultaneamente violento. $O$ artista das flores, dos músculos e veias capturados de forma meticulosa, além do encontro frontal olho a olho do criador e de sua criatura, abrindo no volume máximo seus

\footnotetext{
3 Para Derrida, a literatura como uma invenção moderna dá-se ao direito de tudo dizer. E esse drible não toma como ponto de partida a presença de um segredo que a superfície da página necessariamente lhe traga à luz. 0 secreto está implicado com o sentido do texto, isto é, a necessidade de extrair dele uma verdade, uma finalidade e um aprendizado. Talvez seja este jogo que Édipo não entenda quando escuta os recados do velho Tirésias. Por este motivo, assim como a literatura, podemos pensar que a pornografia está relacionada por sua vez a uma ideia de decência e obscenidade conforme leis modernas (séculos XIX e XX), portanto demanda um regime democrático, cuja trincheira instalará seus sistemas de excesso, éticas e contravenções. (Derrida, 1995:47-48).
} 
corpos arreganhados, não nos dá outra opção: em vez de entender (pressuposto teleológico/racional) ou sentir (romântico-burguês) pensar/sentir/delirar, surgem em fusão. Essa indistinção rasura a chave dicotômica, bipolar do isto ou aquilo e se insinua a partir de uma perspectiva da pós-autonomia: quebra dos padrões e de critérios que conferiam uma dada especificidade da linguagem de arte, criando assim uma desdiferenciação entre pensar, agir, imaginar (Ludmer, 2011: 02).

Essa tríade para Mapplethorpe pode ser lida assim: aquilo que se mostra numa virtualidade de pernas, paus, vaginas, juntas, conectadas à ferocidade das forças indomáveis (ursos, répteis, crustáceos, flores) dispostas horizontalmente na mesma linha da tirania do desejo. Os bodybuilders (Figura 3 e 4) são moldurados por sua lente apenas como uma alegação para devassar outras geometrias delineadas pelo corpo, promessas de forças em estado latente. Outra vez a musculatura, a ossatura que quando capturadas, ficam constrangidas em nossa frente.

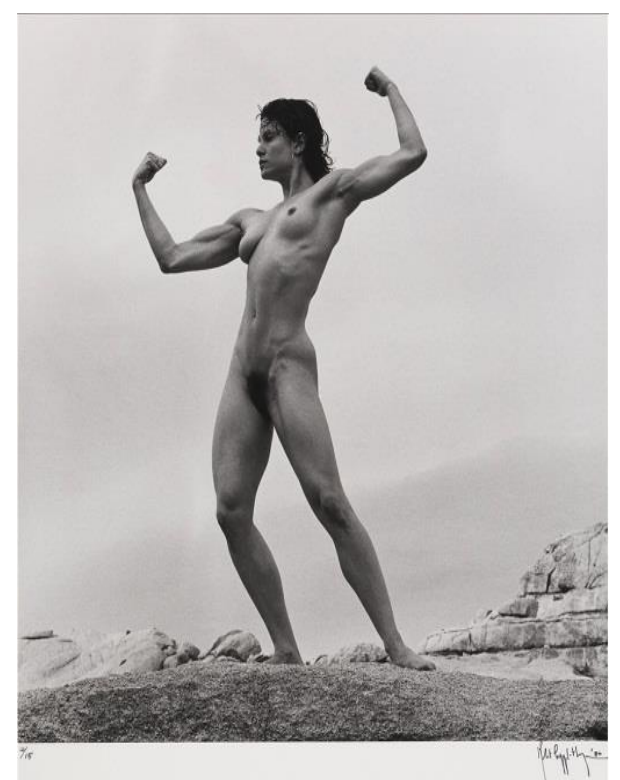

Fig. 3 . Mapplethorpe Lisa Lyon, 1980

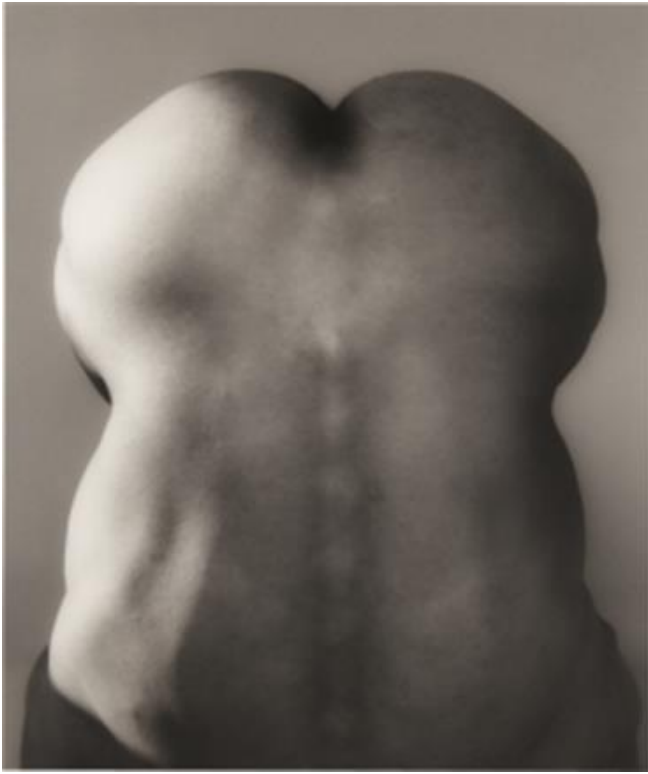

Fig. 4. Mapplethorpe Raymond, 1985. 
A esse esquema que Mapplethorpe obstinadamente se dirige, e investindo o próprio corpo, aquilo que provisoriamente se é; em vista disso não é por acaso que sua carnadura, seus dentes e seus amantes surgem tão intensamente a fim de compor sua cena. Sem eles, sem seus movimentos singulares e banais, fica apenas o deserto do dia a dia contra o qual ele investe toda a energia de sua obra, à medida que seu painel orgiástico ${ }^{4} \mathrm{se}$ mostra como um exercício para amaciar territórios políticos e morais que formam (endurecendo) nosso corpo. Ele, que atravessa os anos de 1970 e 1980 sob a tutela de revoluções (políticas, sexuais, artísticas) tenta entender a realidade em que está alojado através da ficcionalização de quem posa, esconde-se, oferece-se, porque aquilo que reconhece como 0 real só se apresenta no ato de desnudamento e no (des)encontro com quem se deseja. Talvez seja por isso que seus retratos criem ardências, pois as genitálias se mostram com vigor - acesas - trazendo consigo a mesma potência tanto da bala quanto da flor.

No entanto, Mapplethorpe não se interessa demasiadamente pelas formas fálicas e orifícios vulcânicos como parece, mesmo quando admite em entrevistas ${ }^{5}$ que são elas que lhe movem, chamando-lhe atenção, amante das forças em vibração. Daí seu interesse por lançar luz sobre os inchaços e distensões do sexo, do músculo e da produção da dor. Embora seus ensaios provoquem em nós encontros com o que há de orgânico, não nos enganamos, pois o que o leva a retomar mais e mais, a chegar à exaustão em apresentar os detalhes do corpo, é o desejo de exteriorizar essa cartografia, o labirinto do qual nos formamos. Poder desabrigar esses detalhes, desprotegê-los de sua mística, torna-se aqui mais relevante e é o ato que singulariza sua pornografia. Além disso, para Mapplethorpe, sustentar esse gesto de poder mostrar e mostrar(-se) (figuras 2 e 6) compõe a erótica, no mau sentido, de sua arte.

\footnotetext{
${ }^{4}$ Chamo por este termo os personagens que povoam sua obra. No painel encontramos crianças, homens, mulheres, natureza morta, bichos, escultura.

5 É conhecido 0 depoimento do artista que admitiu sua atração por algumas flores devido à sua semelhança com 0 pênis. 
A exterioridade não é aqui oposta a uma interioridade das formas estéticas e teóricas. Não me alio a uma metafísica do profundo cujo modo de leitura opera por oposições (bem e mal, belo e feio, dentro e fora), além de lançar imagens e acontecimentos para outros espaços e origens transcendentes ao sujeito. Como forma de ir-se para além dessas dualidades, Nietzsche rasura a lógica do profundo, das causas e efeitos ao reler os pensadores da filosofia antiga, a fim de quebrantar a matéria fortemente frágil de criação, repetição e uso dos valores atuantes sobre aquilo que construímos como ocidente; sem profundidade, sem afetos oceânicos o exterior celebra, porque só pode contar com ele, as superfícies. Não é à toa que 0 pensamento/arte nietzschiano reposiciona o corpo como campo produtor do agir, do padecer, do sentir, do experimentar: materialidade desenhada cotidianamente por artifícios (atos, sons, imagens) que brandem, acentuando seu aroma, sua cor (Nietzsche, 2006: 97).

Essa linhagem é repotencializada pelo que didaticamente chamamos de teoria e crítica pós-estruturalista: Derrida, Foucault, Deleuze, Silviano Santiano e Josefina Ludmer surgem como principais interventores dessa esteira filosófica (trans)migrados entre nós. Após perdermos os calabouços íntimos, de dentro, sustentados com vigor pelas práticas artísticas e culturais burguesas, ganhamos o tecido, a temperatura, o alimento, as máscaras, os riscos da pele. Ana Cristina César tinha razão: "a intimidade era teatro" (César, 1999:80).

O pornô, acredito, é um elogio ao exterior por não atuar como uma fábrica de segredos, baú - recinto dos guardados. 0 exterior não casa, não forma um par, se entendemos esse laço mais como um encontro de identificação em vez de forças que decidem por em aliança suas terras estrangeiras, seus hábitos estranhos. É curioso que os poucos pares que encontro em Mapplethorpe, atuam sob outro regime de prazer, a partir de outras negociações: da prática sádica e masoquista 6 .

\footnotetext{
${ }^{6}$ Quando encontra tanto as práticas quanto o cenário, os acessórios e personagens da cultura conhecida como sadomasoquista (S\&M), Mapplethorpe passa por dificuldade para expor suas obras, confrontando-se com as 


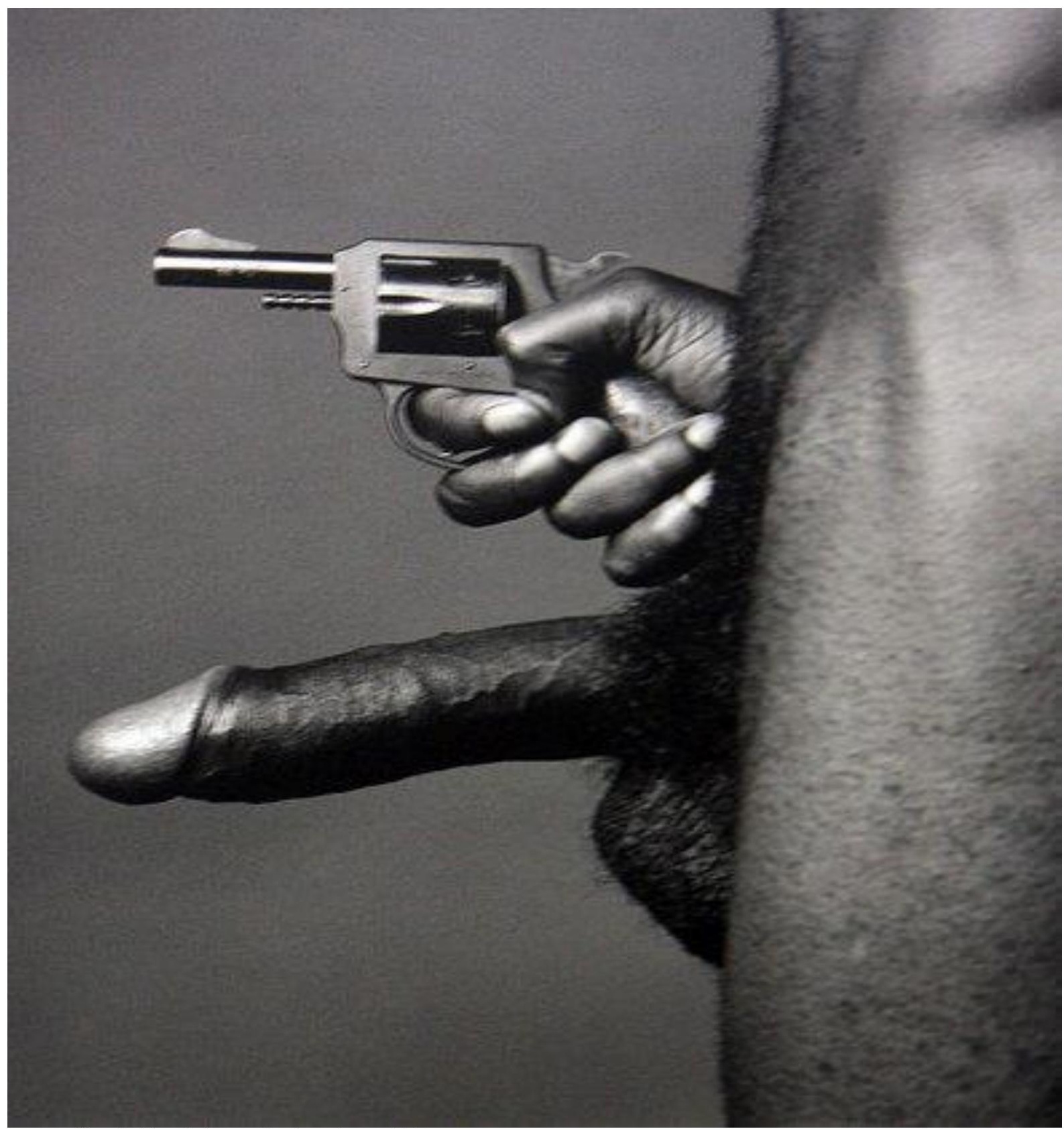

Fig. 5. Mapplethorpe.Cock and gun, 1982.

resistências de galerias abertas à orientações heterossexuais e gays, que em outros momentos acolheram suas imagens fortemente ligadas ao modo de vida homossensual. Esta fase é a mais polêmica do artista, entretanto, por apostar mais em imagens e situações que expandam o pornô naquilo que the é mais estranho e inesperado como 0 beijo, o olhar, a delicadeza, modos de vida e a estetização de práticas cotidianas, esse Mapplethorpe ora sádico, ora masoquista me parece nesta perspectiva muito conservador.

Revista do Programa de Pós-graduação em Arte da UnB V.15, $n^{0} 1 / j a n e i r o-j u n h o$ de 2016

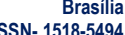


Do modo como os corpos se apresentam diante de seu olhar, parecem eles destituí-lo de um dever em capturar alguma coisa como a essência ou verdade, ligando-o mais ao personagem da testemunha do que de um investigador, pois ele não quer desvelar, descobrir o que encontra preferindo participar, coabitar com as formas físicas (carne, mármore, luz) que se expõem. Transformado em um olho de câmera, Mapplethorpe também se oferece para o corpo nada surpreendido pelo seu flash. Pelo contrário, os corpos que se ofereceram ao seu olhar parecem (se) encenar, dramatizando delicadamente gestos e olhares; por outro lado, como todo 0 corpo está reencenado (estranhamente vestidos, coreografados, geometrizados), descentraliza a supremacia das genitálias, ato que instaura uma relação diferente e inusitada com os detalhes mais inesperados da cena: mãos suspensas, incorporação dos acasos, objetos outros no arranjo do acontecimento (de armas de fogo, mão que escreve, sapatilhas de balé às expressões melancólicas). Tudo vem se juntar à nudez impossível dos corpos.

\section{Diante de tulipas, 0 olho}

Após a visita a uma galeria que abrigava a performance de modelos vivos e nus diante de uma plateia e o mútuo desconforto (dos artistas e do público), Agamben afirma sobre a impossibilidade do ato de desnudar-se. Tomando como base os personagens bíblicos de Adão e Eva, o pensador das corporeidades nuas diz que há uma espécie de "graça" que fora lançada ao corpo, uma profundidade, camadas em que estar nu entre nós ocidentais fica sendo uma ação que remete veladamente a um ponto em que a nudez se torna inacessível, pois a consciência de se possuir um corpo conferiu-lhe uma sacralidade. Esconder as genitálias com uma folha para Adão e Eva é a tentativa de preservar do olhar alheio o que deve permanecer resguardado.

A nudez, na nossa cultura, é inseparável de uma marca teológica. [...] A olhos tão profundamente (ainda que inconscientemente) condicionados pela tradição teológica, o que aparece quando se tira as vestes (a graça) não é mais do que uma sombra [grifo nosso] delas, e libertar totalmente a nudez dos esquemas que 
nos permitem concebê-la apenas de modo privativo e instantâneo é uma tarefa que requer uma lucidez fora do comum (Agamben, 2010: 73 e 81).

Ao aliar-se ao seu objeto, somos dessa vez nós as testemunhas, os espectadores não de uma cena, senão de um processo colaborativo e relacional que aquele que se invisibiliza, Mapplethorpe (nascido em 1946 nos EUA, fotógrafo, escultor, leitor de Jean Genet), torna-se o sujeito devassado por seus modelos e de outras naturezas vivas/mortas. A visada desses corpos-em-cena desloca o lugar tradicional do observador das artes visuais: o corpo que vê assume seu lugar como voyeur, ou decide ir além, transformando-se em outra matéria que participa, que ocupa com malícia, a situação?

Os papéis se reverteram, pois é ele então a prenda, a sutileza, a oferenda? "Eu me submeto ao meu objeto. O acompanho, relacionando minha personalidade com quem estou fotografando... Não fotografo coisas com as quais não me envolvi" (Mapplethorpe apud Dobranszky ,2005). 


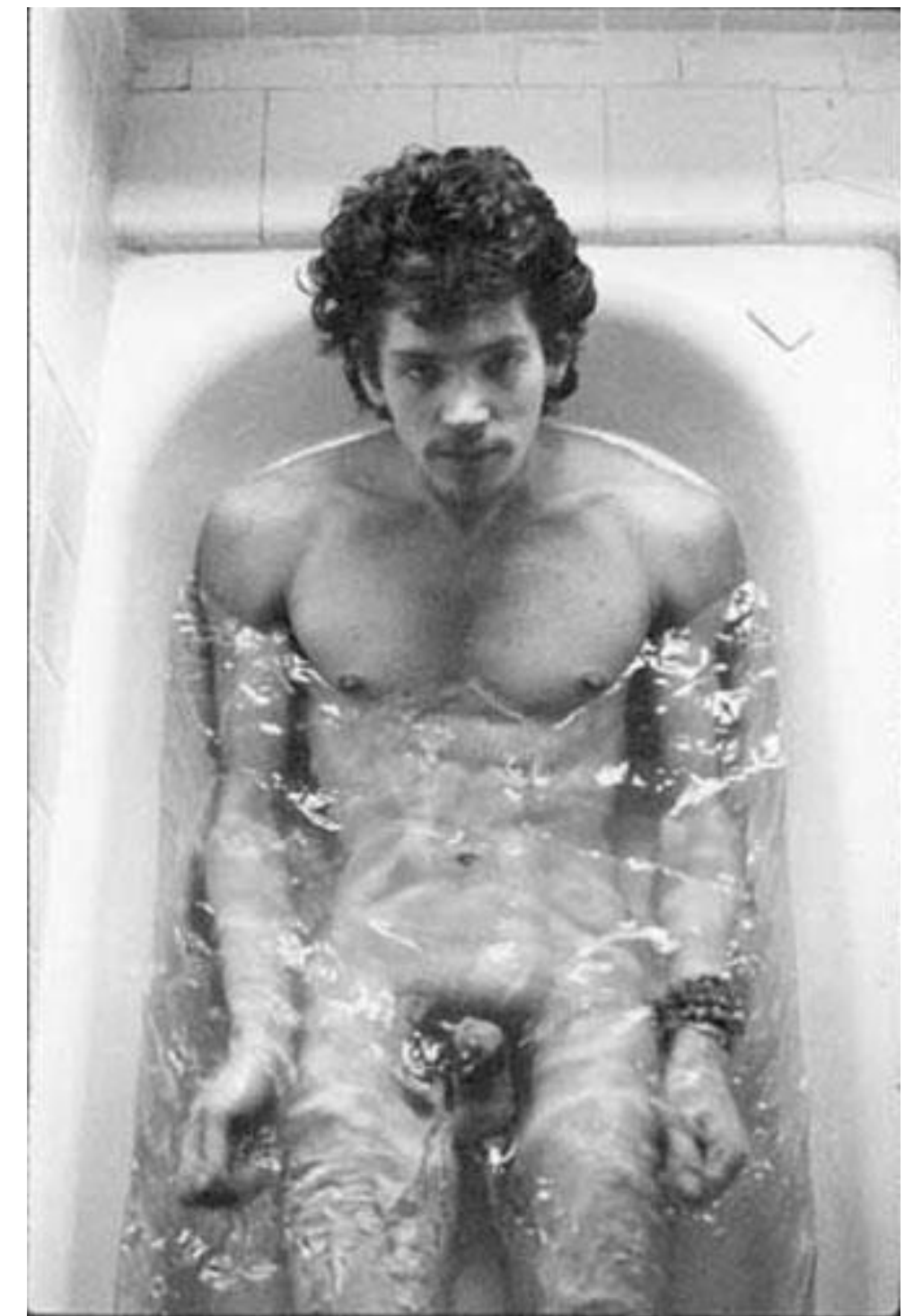

Fig. 6. Mapplethorpe. Selfportrait, 1972.

Daí o interesse em cultivar uma espécie de floricultura silvestre em que sua flora deixa-se confundir - mantendo suas particularidades - com o corpo. $\mathrm{E}$ seu ato de murchar não sinaliza sua fragilidade diante do tempo, mas uma resposta à violência de arrancá-las e prendê-las entre as mãos. E é neste instante, sobre a linha do perecível e do selvagem, que essas naturezas meio vivas e mortas entram em diálogo para visitar as forças umas das outras. Aqui começa sua sensualidade, quando perdem cada parte sua rigidez e como um pêndulo, ganham vida na oscilação. 


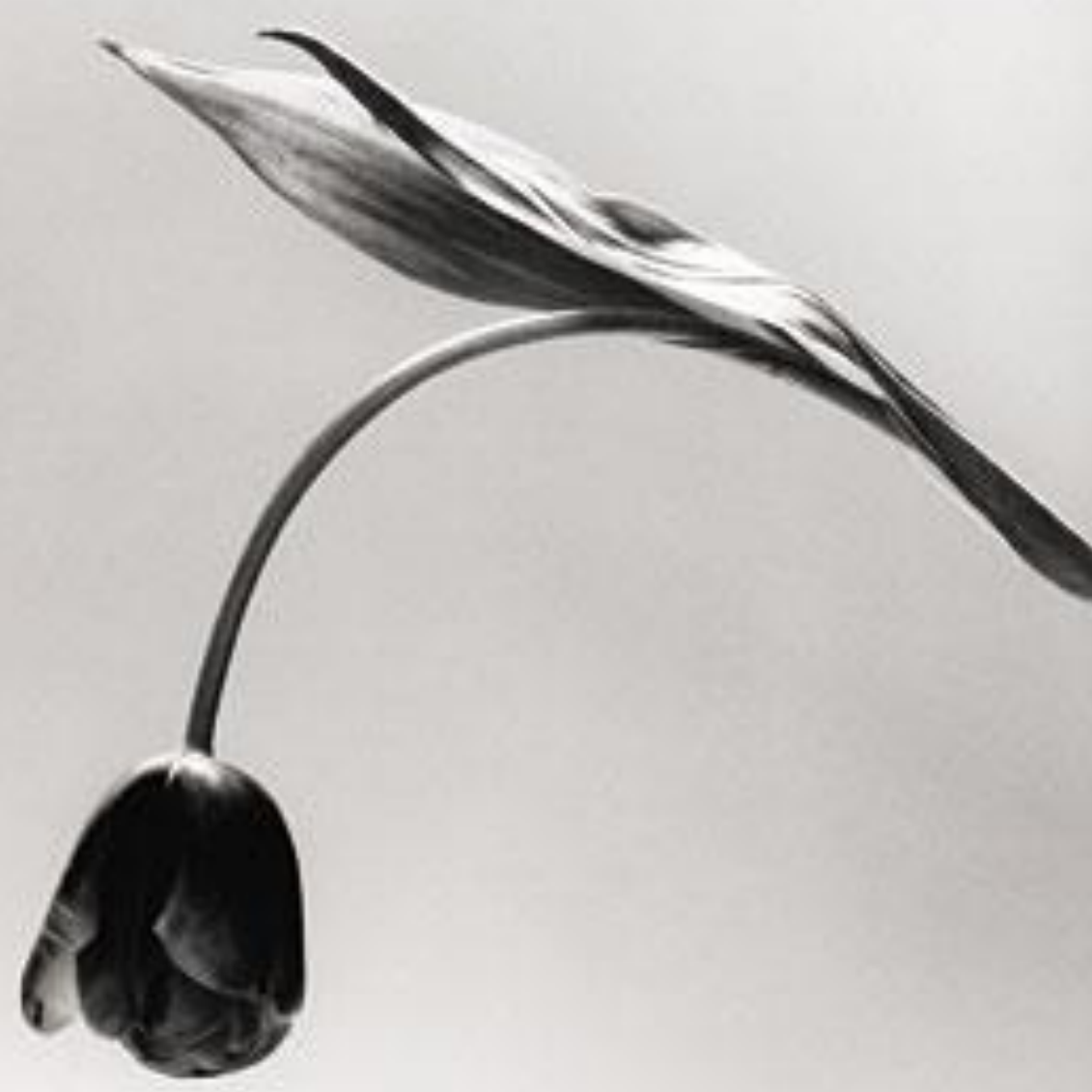

Fig. 7. Mapplethorpe, Tulip, 1984.

A ferocidade de sua botânica não fica entrecortada no limite imaginário da moldura; em vez disso, ela nos impõe contato. Aliás, quando suas orquídeas, lírios, papoulas e íris ganham diante de sua lente ora uma forma fálica, ora uma forma murcha e desbotada, é porque ele, Mapplethorpe, neste instante está oferecendo uma a uma como elementos possíveis para fazer parte de outro banquete. Neste mínimo movimento que capturamos seu lirismo e simultaneamente sua carnificina. Aí, acreditamos que se 
encontra certo nomadismo, graças a essa possibilidade de habitar diferentes jogos, grupelhos, imaginários e fronteiras.

Mapplethorpe provoca entre as duas esferas do erótico e pornográfico, apontando para um caminho em que a arte contemporânea vai acolher em seus diversos modos de fazer: o estar-entre em relação ao espaço, linguagem, sistemas, fronteiras, tradições. A inespecificidade do fotógrafo estadunidense encontra-se espraiada no campo de produção que teima em não se resolver entre a escultura, fotografia e colagem, assumindo deste modo o entre, o meio não como forma de driblar ou escapar a uma decisão, mas como maneira de (con)viver entre elas, aquelas e outras.

Viver na encruzilhada entre a tradição fotográfica do preto e branco, do nu, do enquadramento, ou no meio das poses inertes da escultura, estar entre a dormência, 0 corpo doente ${ }^{7}$ e a saúde do fazer, respirar mesmo quando há o mau tempo enquanto os amigos pouco a pouco desaparecem, se torna o princípio ativo de seu pornolirismo. A espetacularização do orgânico vista entre os paus, os músculos, as flores lhe interessam - imagens bacantes, eretas em suas medidas, em seus volumes e divinas - porque mostram no limite do corpo suas potências. "É no meio que há o devir, o movimento, a velocidade, o turbilhão. 0 meio não é uma média, e sim, ao contrário, um excesso. [...] E um autor menor é justamente isso: sem futuro nem passado, ele só tem um devir, um meio pelo qual se comunica com outros tempos, outros espaços." Deleuze (2010, p. 35).

Quando convida animais selvagens e corpos não normativos para sua cena, ele interfere naquilo que seria historicamente a finalidade do pornográfico, sua nuance teleológica - a excitação - lugar comum das obras vistas nesta vertente, efeito de práticas sociais que se esforçaram para reprimir a libido dos corpos. Onde há cabeça de urso, há também sexo,

7 Devido às complicações decorrentes da AIDS, Mapplethorpe morre em 1989. 
Salvador Dáli e escorpião ${ }^{8}$. Estas figuras dramáticas propositadamente destoantes compõem o cenário nada corriqueiro nem familiar de sua arte pornográfica.

\section{O campo ampliado do pornô}

Rosalind Krauss em seu famoso e instigante ensaio Sculpture in the Expanded Field ${ }^{9}$ anunciava no final da década de 1970 sobre a dificuldade em nomear uma série de obras, cujo aspecto de estranhamento devido à composição de seus elementos, problematizava o que se conhecia por escultura. O que escapa desse lugar é o que vemos e no entanto não reconhecemos como familiar diante de uma imagem em que a identificação e as convenções tiveram de ser levemente traídas para tornar possível seu nascimento. Para alocar as modelagens que surgiam, dizia a crítica de arte norte-americana, seria preciso tornar o conceito maleável (Krauss, 2008:128). Ao deparar-se portanto com feitos plásticos forasteiros demais para essa arte do monumento, coube à crítica e teóricos elastecerem o território do escultural a fim de acolher algumas práticas, isto é, esticar, aumentar o tamanho, distender, estirar, amplificar, desenrolar, desdobrar, expandir o solo, o terreno, o pasto, o plano, o campo do acontecimento.

Krauss tem sido retomada por aqueles que se interessam em pensar 0 contemporâneo no que tange às suas formas e aos seus critérios estéticos, antes, ainda bem delimitados no campo das artes modernistas do movimento e dos ruídos (dança, performance, música), (áudio)visuais (cinema, teatro, pintura) e de ocupação (arquitetura). Quem contestaria que o uso da canção, da linguagem dos esportes, do pensamento político só fez tornar o teatro supermoderno de Brecht, mesmo na contracorrente, cada vez mais teatral? O contemporâneo acontece segundo as provocações de seus objetos e situações cuja demanda solicitará

\footnotetext{
8 Personagens de seu bestiário (animais indomesticáveis) e celebridades do mundo das artes integram-se na paisagem de seu portfólio.

${ }^{9} \mathrm{O}$ artigo foi afetuosamente traduzido e publicado pela Revista do Curso de Especialização em História da Arte e Arquitetura no Brasil (PUC-Rio), com primeira edição em 1984 e reeditado em 2008. A primeira versão da autora foi posto em circulação em 1979. (Krauss, 2008). 
posicionamentos outros, quanto ao teorizar e se relacionar com essas dissidências plásticas. A discussão, espantosamente óbvia de Krauss, nos leva como se estivéssemos a bordo de um maquinário supersônico de volta a um passado, a fim de revisitarmos os tópicos supostamente resolvidos de tão esgotados tanto nas abordagens críticas quanto teóricas, levando assim os personagens envolvidos - artista, obra, espectador, crítica - a retomarem o debate de conceitos fundamentais no universo das artes.

O campo ampliado não obedece aos sistemas verticais em que vemos sustentados as ditas linguagens ou disciplinas de arte como a literatura, o cinema, a pintura, a fotografia, a performance. Quando ampliados, esses territórios - antes densamente concretos embora paralisantes a partir de critérios segundo o gênero, autoria e representação - ganham matéria tornando-se flutuantes numa atitude de desobediência a pertencimentos e filiações. O contemporâneo alarga (ferindo) os acordos modernos das fronteiras e defesas dos campos, para propor a experiência com o limite, levando o artista a viver numa dobra, explorando na superfície da tela/página/pele os limiares e as bordas, tão imaginárias quanto seus centros. Não mais uma coisa ou outra, nem apenas uma e outra, mas coisas com coisas além de mais outras de tal modo que o território perigue perder o nome e a própria solidez de sua terra. E perde.

Como não lembrar dos uivos da mulher com uma criança nos braços ${ }^{10}$ entre a terra de ninguém e a terra dos homens:

Quero atravessar essa fronteira, pois eu não pertenço mais a nenhuma dessas novas pátrias saídas do âmago da minha grande pátria antiga. Minha nacionalidade é a terra. Minha nacionalidade é o céu estrelado em cima de minha cabeça. Minha nacionalidade é 0 vôo dos passarinhos que voam acima das fronteiras. Quero ter a mesma nacionalidade que as nuvens que flutuam acima da nossa terra. Minha nacionalidade é o vento. Quero ter os mesmos direitos que 0 vento, os passarinhos e o céu estrelado (Visniec, 2013: 25-26).

Embora as obras no campo ampliado povoam, por assim dizer, "uma terra de ninguém/no man's land", pois a dureza de certos vocábulos como

10 Texto que integra o chamado teatro da ternura e da loucura cotidiana do dramaturgo contemporâneo Matei Visniec. 
características, poética e cânone são ainda operados, porém mantidos estrategicamente nos debates e teorias de artes. Daí que o expandido neste jogo aditivo horizontaliza as forças para que não caia na armadilha da inversão, pois invertendo não se muda a qualidade da matéria, não há transformação. Na inversão, mantêm-se satisfatoriamente artigos definidos (a fotografia, a pornografia), preposições e locuções volumosas (sobre cinema, falar em nome de), além de contextos históricos e subjetivos, nomenclatura. Horizontalizar como uma imagem-ação que desarquiteta 0 peso do termo sobre, dispersando os amontoados e fazendo de seus entulhos peças de arte.

Escavar nos primeiros acordes dessa temática não é o retorno com 0 propósito de apreender uma origem, tocar num caroço, salvar um nome, um pensamento, uma língua, um hábito de seu passado, da violência do esquecer: o retorno se firma paradoxalmente para resgatarmos o tempo presente, fazendo instantaneamente do caminho ao regressar um espaço de criação. Difícil não lembrar a leitura espirituosa de Didi-Huberman ${ }^{11}$ :

Mas o escultor investe todos os sentidos do tempo. Escavar não é unicamente abrir a terra para tirar dela coisas mortas há muito tempo. É também manejar na terra aberta- lavada, "lavorada" como se dizia antigamente -, uma passagem para formas com memória de seu devir, de seu nascimento e crescimento futuros (2009:56).

No contemporâneo, discutir sobre aspectos básicos de uma linguagem não consiste numa vontade de demarcar fronteiras nem de abrandar 0 arrebatador, historicizando-0, dando-Ihe uma tradição, destinando-lhe a uma família: simboliza, aliás, uma tentativa de conviver, aproximar-se de técnicas desviantes do sentir e do ver lançadas no ar pelas materialidades estéticas indomáveis, resistentes à categorização. Sem o desejo de representar nem significar, somos convocados a participar de seu regime

11 Didi-Huberman se interessa pelas esculturas do artista italiano Giuseppe Penone cujos objetos propõem no campo do contemporâneo outros modos de ver, estar perto e aproximar-se, produzindo a partir do escultural uma abordagem paradoxal da matéria, da memória e do gesto. (Didi-Huberman, 2009). 
de desmontagem de barreiras para compor uma nova arte do encontro e da coabitação de espaços ${ }^{12}$.

No filme Baby of Macon (1993), o cineasta britânico Peter Greenaway ${ }^{13}$ usa como cenário um palco de teatro em que as ações se desdobram ao longo de toda duração cinematográfica, de modo que, se o espectador e a obra não tivessem salvaguardados pelos sinais paratextuais (tela, imagem, imaterialidade dos corpos), poder-se-ia desconfiar que se estivesse diante de uma peça de teatro. Mais do que um diálogo entre dois distintos modos de fazer e experimentar (cinema, teatro), Greenaway aposta num embate conflituoso em que todos os envolvidos perdem suas referências de gênero e lugar, estatuto e categoria, pois são desafiados a sustentar o convívio com a fenda, a borda, o limite. Este campo ampliado do pornô é povoado por muitas formas e também desertificado por cada uma delas. Sua história só pode ser contada se considerarmos as pegadas, rastros e trilhas esquecidas ao acaso. 0 chão que sustenta seus contornos, que esconde suas raízes é uma junção dessas materialidades facilmente desmontáveis pelo vento e pelas águas.

Uma pornografia fora de si seria em primeiro plano essas imagens artísticas que rasuram o que se convencionou chamar de pornográfico, à medida que in-corporam em sua tessitura elementos aparentemente desconectados, produzindo outros níveis de afetação. Hélio Oiticica (1937-1980) reverte a relação entre o suporte/obra/espectador a partir da criação de seus parangolés, investindo no que chamou de in-corporação: ao dançar e vivenciar o parangolé, o corpo in-corpora-se na obra e esta no corpo, criando um ambiente de simultaneidade entre elas. 0 espectador, com seu

\footnotetext{
12 Gustav Deutsch (2014) refaz meticulosamente treze pinturas do artista estadunidense Edward Hopper (1882-1967) como cenário do filme Shirley: visions of reality, distendendo ao máximo os fios entre a pintura e imagem audiovisual. A mimetização ganha uma nuance diferente, uma vez que suplementa as imagens dando-lhes o que de fato a arte da pintura não precisa, pois Deutsch parece sonorizar os quadros de Hopper quando capta seus instrumentos de trabalho (cor, enquadramento, movimento) impressos na tela.

13 As obras de Peter Greenaway estão sempre pondo o estatuto do cinematográfico em choque e ebulição, particularmente com as artes plásticas. Prefiro destacar três longas como: 8 1⁄2 Women (1999) e A Última Tempestade (1991). Em O livro de cabeceira (1996), ele aposta no corpo como suporte do literário e do pictórico. Este filme pode ser lido (por que não?) como um poema visual. 
olho e suas experiências, não fica a salvo desse processo, aliando sua mirada e gestos sobre a obra que se agita diante dele. $\mathrm{E}$ deriva desse encontro a forma do parangolé: corpo, movimento, som, cor e olho. Nicolas Bourriaud opera com um conceito de arte relacional para aproximar-se de algumas criações artísticas a partir da década de 1990, cuja imaterialidade e a relação entre arte e o espectador coexistem na criação e sob a mesma frequência. Diz:

Esse regime casual intensivo, elevado à potência de uma regra absoluta de civilização, acabou criando práticas artísticas correspondentes, isto é, uma forma de arte cujo substrato é dado pela intersubjetividade e tem como tema central o estar-juntos, o "encontro" entre observador e quadro, a elaboração coletiva do sentido. (2009: 21).

Ao acolher elementos de outras linguagens e, sobretudo, provocar um distanciamento, esse não-lugar distancia-se do dueto opositivo (erótico e pornô, alto e baixo, superficial e profundo, arte e não arte) quando solicita outros modos de leitura e experimentação, vivenciando sua dissidência política e crítica via sua inespecificidade. 0 inespecífico surge como um dispositivo teórico que acolhe obras produzidas e dispostas no campo do contemporâneo cujas noções de pertencimento a um gênero, território e temporalidades desmantelam-se. A pensadora argentina Florencia Garramuño (2014) trabalha com o inespecífico lendo obras de artistas que chamam para seu jogo diferentes linguagens e matérias, reclamando outras categorias e desdobramentos teóricos e afetivos. Este não lugar também se move, à proporção que ele faz dessa deriva seu alimento.

Frutos estranhos e inesperados, difíceis de ser categorizados e definidos, que nas suas apostas por meios e formas diversas, misturas e combinações inesperadas, saltos e fragmentos soltos, marcas e desenquadramento de origem, de gêneros em todos os sentidos do termo - e disciplinas, parecem compartilhar um mesmo desconforto em face de qualquer definição específica ou categoria de pertencimento em que instalar-se. Algumas dessas obras se equilibram num suporte efêmero ou precário; outras exibem uma exploração da vulnerabilidade de consequências radicais; em outras ainda o nomadismo intenso e o movimento constante de espaços, lugares, subjetividades, afetos e emoções tornam-se operações que se repetem vezes seguidas. Mas todas elas revelam, em seu conjunto - para além das diferenças formais entre elas -, um modo sempre de estar fora de si, fora de um lugar ou de uma categoria próprios, únicos, fechados, prístinos ou contidos. (Garramuño, 2014:12). 
O fora de si, é importante pontuar, não surge como uma tentativa de afastar ou retirar essas obras de Mapplethorpe do estatuto do pornô, o que acusaria de nossa parte um gesto moral, senão ressaltar que este lugar aparentemente bem mapeado, nenhuma pureza guarda, pois se mantém em diálogo com outras vozes e linguagens artísticas, mostrando um campo expandido do pornográfico. Se há vaginas, cus, pentelhos e paus, se há pretos, brancos, flores, artistas e fisiculturistas - essa mistura em preto e branco - é o modo mais decente dele expor sua devassidão, ele que foi desenhado por e ao mesmo tempo engenheiro e herdeiro das ruínas cintilantes da década de 1970 .

Quanto ao vazio e o puro frenesi sexual (considerados como elementos que atestam a pobreza do pornô), Mapplethorpe não os despreza no jogo com seu espectador, entretanto institui outros modos de narrar, criar e usar ${ }^{14}$. A sutileza de seus enquadramentos, afirma o diálogo que mantém com certa tradição visual, a exemplo de Hendrick Goltzius e Jan Harmensz Muller ${ }^{15}$.

Convencionou-se aliar uma certa pobreza impotente aos livros, filmes e outras imagens de artistas que tracejam o que chamamos em outro lugar de um rastro pornô. Lemos o pobre nesta estética através da ousadia gestual em abrir mão de uma completude - corpo, narrativa, grandes afetos - cuja aposta volta-se insistentemente aos inacabamentos, ao residual. Desde os sonetos dos poetas venezianos (Aretino, Beradinelli) cujo escândalo de seus versos explica-se mais pelo foco nos minimalismos físicos do que na legitimação de uma língua vulgar ${ }^{16}$, que testemunhamos

\footnotetext{
14 A atitude de expor seu trabalho em galerias e museus talvez possa ser entendida não como um desejo de institucionalizar e/ou legitimar suas obras, mas a tentativa de construir outros espaços para as questões abordadas pelas imagens, criando, assim, contracorrentes. Lembro-me do que Foucault chamava de ficarmos atentos para 0 pequeno intenso gesto das brechas, fissuras, microfendas, isto é, abrir cortes naquilo que mostra-se mais forte e resistente historicamente à nossa aproximação e presença e que nomeamos como sistemas (econômicos, políticos, linguísticos), famílias (artísticas, epistemológicas, sanguíneas, comunitárias), conglomerados, associações. (Foucault, 2010).

15 Conforme mostra artigo de Dobranszky (2005) sobre a relação de Mapplethorpe com a tradição clássica.

16 Chamo de vulgar os referentes que compunham uma linguagem dita popular, tão repudiada na tradição da lírica moderna ocidental, gênero literário tradicionalmente visto como o território do sublime e do belo. Essa perspectiva começa a ser rasurada em diferentes tempos e espaços (Bocage, Rimbaud, Baudelaire, Gregório de Matos), entretanto, é na explosão das práticas e manifestos modernistas que veremos suas rupturas, disseminadas e descentradas ao redor dos diferentes cenários artísticos da Europa, EUA e os países da América Latina. No campo 
o desenquadrar do corpo, e dessa dissecação elegeremos como indecentes, devassas, diabólicas, superficiais, não-arte imagens que reapresentarem de forma mimética ou não o cu, o pau, a vagina e os nossos desejos mais do fundo, como efeito de uma superfície discursiva.

"Perguntei se estava em seus planos vir me incomodar todas as noites. Eu o incomodo?, disse. Ela me olhava, sem dúvida. Não devia estar vendo grande coisa. Duas pálpebras talvez, e um pouco de nariz e de testa", diz o personagem de Beckett (2004:06). Essa passagem já sinaliza no início do século XX diversas práticas narrativas e principalmente, acima de tudo, no terreno da dramaturgia cujos personagens, cenários e ações só são possíveis de serem mostradas aos pedaços. É no rasgo do tecido desbotado que os fios mais delicados serão flagrados. É na economia não apenas das palavras, mas do próprio corpo que uma meia história, quase história ou mesmo uma história de ninguém é contada.

Só através da expressão um pouco de, que se esclarece o encontro e que se desdobra um emaranhado de poéticas artísticas (da poesia- pílula ao teatro pós-dramático) no início do século XX ao tempo presente, e que será acolhida e reengenhada por incendiárias máquinas artísticas (Thomas Bernhard, Matéi Visniec, Heiner Müller) e teóricas (Roland Barthes e seus fragmentos, Derrida e sua língua oblíqua, Roberto Correa dos Santos e suas performances poético-ensaísticas) além de vir a ser um hábil operador de leitura em relação aos objetos pornográficos de múltiplos trabalhos de artistas no campo do contemporâneo ${ }^{17}$. Um pouco de, antes de atestar uma carência, desenha modos e esquemas, quadros e partituras de afecção.

do contemporâneo, o lírico espraiou-se para outros feitos de arte, sendo encontrado desde o filme documentário à arquitetura, o drama lírico à performance, das artes da/na rua às encenações teatralizadas do cotidiano à publicidade. O lírico, assim como a pornografia no que se refere à performance, espetacularização do privado, música popular, vem construindo historicamente outros suportes de enunciação.

17 Não vamos esquecer os textos e os projetos estéticos que foram subitamente brecados devido à loucura/suicídio/ameaças militares ou a morte de seus inventores e que ainda assim constituem mesmo na sua incompletude uma obra, uma força estética e discursiva, dentre eles \& elas: Georg Büchner e Woyzeck, Artaud e seu teatro da crueldade, Albert Camus e sua autobiografia. 
Apenas no rudimentar, no pedaço ocre do osso, diria um arqueólogo, que se encontra o corpo todo de um tempo longe, fora de nós.

Essa recusa, esse sistema da antifartura parece posicionar a obra de Mapplethorpe numa cruzada estética que fratura performances do pornô sob a regência do excesso. Como concentrar ao máximo fusões altamente ativas, refiro-me às muitas misturas que compõem as imagens (do afeto, do experimento, da duração) no quadrado da lente, da moldura, do espaço fendido na parede sem cair na armadilha daquilo que periga exceder-se? Paixões muito intensas, diz Nelson Rodrigues sobre seus personagens, viram sobra, efeito do excesso, amor barato. Eis aí uma postura que fragiliza o capital pornô: a abundância de corpo, imagem e o direito ao gozo para todos não imobiliza a fabricação em massa de narrativas sobre a falta de prazer. O tédio como sobra do excesso? Não é Thomas Bernhard quem diz que nossos olhos nos enganam quando deixam de ver as povoações, as estradas, os exércitos em marcha, os reinos, os jardins e cemitérios suspensos que habitam a parede? (1992: 64)

Paradoxalmente, a lógica do detalhe se inscreve (pelo menos entre nós no Brasil), de modo mais intenso nas produções literárias dos séculos XVIII e XIX. O detalhe como um procedimento destrinchado ao máximo nos textos românticos e realistas. Nestes, conhecemos objetos, a temperatura do ambiente, a intimidade dos personagens, a textura do alimento sobre a mesa, a ardência dos desejos, somos espectadores das franjas e arrepios da pele, da queda ziguezagueante dos fios de cabelo. Criam o detalhe na mesma proporção que o avolumam, concentrando sobre ele uma rajada de luz em que nada escapa ao olho tanto de quem conta (narrador) quanto de quem coparticipa (leitor, espectador). O contemporâneo, no entanto, lança mão dessa tentativa de construir um universo. Ele decide produzir a partir de um detalhe, mas esse dado é rapidamente abandonado, isto é, o toque, o encontro que disparou a parafernália criativa do artista. A energia do olho que flagra as minúcias é, no tempo corrente, uma arte de captura e invenção numa paisagem superpovoada por imagens. Eis aqui um 
pressuposto contra nossas riquezas empobrecidas, os excessos vazios consumidos e patrocinados avidamente no espaço do cotidiano.

Deste modo, a pobreza como uma tarja que rebaixa a potência do pornô, ao que parece e caso haja, fica restringida às suas produções mainstream. Chamo por este termo mainstream (corrente principal, fluxo principal, dominante), sobretudo uma linguagem mais compromissada com políticas de mercado e fabricação de estereótipos do que com a relação com o pornô enquanto elemento de arte e os possíveis efeitos desse posicionamento. Com o propósito de produzir uma crítica às políticas sexuais, posicionando as mulheres, todas elas, como sujeito do prazer e alargando ao mesmo tempo modos de realização do pornô, surgiram termos como póspornografia, pornofeminismos, pornoterrorismo:

Inadequadas para os critérios do feminismo mas feitas [...] por mulheres estas práticas artísticas parecem cair num vazio historiográfico, reinvidicando novas categorias (pós-pornografia, vídeoarte e performance pornoterrorista) desde as que se conectam à retícula do visível. Podia apressar-me aqui a construir uma história pos'-pornográfica da arte que, propondo suas próprias noções de sujeito, olhar, representação e prazer, construa um relato alternativo ao proposto por uma historiografia próidentitária com seus novos ingressos feministas e da arte gay (Preciado, 2008: 42-43)

Mapplethorpe assina em suas molduras nômades, na vida, um fascínio pelo detalhe - pela discreta arte de isolar - a partir de uma totalidade, um pedaço de corpo, um resto de carne, uma mania, uma promessa de dor, a beleza das flores mortificadas. Ele quer saber, por este motivo, ele comparece, convida, vasculha, fotografa, toma a frente, se estampa, se junta, goza e abandona os elementos vivos e mortos que se estendem diante dele para compor sua cena. Isso é tudo, isso é muito. Instala-se aí o seu mais além: o seu pós-pornô, o aromático. Mapplethorpe sabe dessa sina do fotógrafo inscrita como uma ferida: operar, mostrar o máximo que puder por meio de um retalho, de sobras. 
É contra a cultura do miniatural, do detalhe e a favor do sistema dos guardados, isto é, do preservado e sacralizado, que se justifica a censura18 sofrida (aqui e ali) pelos seus objetos de arte ao longo de seus quase vinte anos de atividade fotográfica.

\section{Referências}

AGAMBEN, Giorgio. A potência do pensamento. Belo Horizonte: Autêntica, 2015. Profanações. São Paulo: Boitempo, 2007. . Nudez. Lisboa: Relógio d'água, 2010.

ALVES, Moisés Oliveira. Roçar (nos bichos pretos coloridos): gesto, pornô e afeto. eRevista Performatus, Inhumas, ano 4, n. 15, jan. 2016. ISSN: 2316-8102.

BARTHES, Roland. A câmara clara: nota sobre a fotografia. Rio de Janeiro: Nova Fronteira, 2012.

BECKETT, Samuel. Primeiro amor. São Paulo: Cosac e Naif, 2004.

BENJAMIN, Walter. Experiência e pobreza. Trad. Sérgio Paulo Rouanet. In: . Magia e técnica, arte e política. São Paulo: Brasiliense, 1985.

BOURRIAUD, Nicolas. Estética Relacional. São Paulo: Martins Fontes, 2009.

CASTELLO BRANCO, Lúcia. O que é o erotismo. São Paulo: Brasiliense, 2004.

DERRIDA, Jacques. Paixões. Campinas: Papirus, 1995.

MCDONALD, Ronald. Censored. Revista The Advocate, Ano, 1978. Disponível http://www.queerculturalcenter.org/Pages/Mappleth/MappMcD.html. Acesso em 15 de Setembro de 2015.

DIDI-HUBERMAN, Georges. Ser Crânio: lugar, contato, pensamento, escultura. Trad. Vera Casa Nova. Belo Horizonte: C/Arte, 2009.

\footnotetext{
18 No ano de 1978, conforme vemos no artigo de Robert MacDonald (1978), da revista The Advocate, o nome da exposição Censored (Censurado) retrata a dificuldade do fotógrafo nova-iorquino em achar uma instituição de arte para expor seus trabalhos, sendo acolhido por espaços não convencionais como o 80 Langton Street (uma espécie de instituição não-comercial nos arredores da zona industrial de São Francisco/EUA). Censored reuniu dezenove imagens cujo foco se voltou para a cultura S\&M vivenciada e ficcionalizada por Mapplethorpe. De todos os contrainvestimentos, foi por meio dessa poesia da dor, que ele encontrou tanto de gays e não gays as mais fortes resistências à circulação de seu trabalho: Ao realizar fotos da cultura S\&M, a proposta de Mapplethorpe visa documentar experiências humanas que até este instante tem sido ignoradas ou suprimidas. Os fãs do S\&M, embora uma minoria tanto entre gays e não gays, são humanos. O que se percebe nas imagens de Mapplethorpe são uma força física dos sujeitos e uma ternura de seus ajudantes na exploração de uma poesia da dor.
} 
FOUCAULT, Michel. A história da sexualidade: a vontade de saber. Rio de Janeiro: Graal, 2011, p. 77.

Ditos e escritos III. Estética: literatura e pintura, música e cinema. Rio de Janeiro: Forense, 2009.

GARRAMUÑO, Florencia. Frutos estranhos: sobre a inespecificidade na estética contemporânea. Rio de Janeiro: Rocco, 2014.

HUNT, Lynn (Org). A Invenção da Pornografia: obscenidade e as origens da modernidade 1500-1800. Trad. Carlos Szlak. São Paulo: Hedra, 1999.

KRAUSS, Rosalind. A escultura no campo ampliado. Rio de Janeiro: PUCRevista do Curso de Especialização em História da Arte e Arquitetura no Brasil, 1984.

LUDMER, Josefina. Notas para Literaturas Pós-Autônomas III. Revista Sopro. Disponível em www.culturaebarbarie.org/sopro Acesso em 18 de Julho de 2015.

NIETZSCHE, Friedrich. Crepúsculo dos ídolos. Trad. Paulo César de Souza. São Paulo: Companhia das Letras, 2006.

PRECIADO, Beatriz. Museo, Basura urbana y pornografia. Zehar: revista de arteleku, $n^{0}$ 64, 2008, p. 38-67.

SANTOS, Roberto Correa dos. Cérebro-Ocidente/Cérebro Brasil: arte/escrita/vida/pensamento/clínica/tratos contemporâneos. Rio de Janeiro: Circuito, 2015.

VISNIEC, Matei. Espere o calorão passar. IN: Cuidado com as velhinhas carentes e solitárias. Rio de Janeiro: É realizações, 2013.

WILLIAMS, Linda. Film Bodies: Gender, Genre, and Excess. University of California Press. Film Quarterly, Vol. 44, No. 4, 1991, p. 2-13.

Screening Sex. Revelando e dissimulando o sexo. Campinas: cadernos Pagu, nº 38, 2012, p. 13-51. 